\title{
Effects of Sewage Sludge Biochar on Soil Characteristics and Crop Yield in Loamy Sand Soil
}

\author{
Junjian You', Lei Sun¹, Xia Liu' ${ }^{1 *}$ Xuli Hu², Qiang Xu' \\ ${ }^{1}$ Jiangsu Key Laboratory of Soil and Water Conservation and Ecological Restoration, \\ Collaborative Innovation Center of Sustainable Forestry in Southern China of Jiangsu Province, \\ Forestry College of Nanjing Forestry University, Nanjing, China \\ ${ }^{2}$ Monitoring Center Station of Soil and Water Conservation, Huaihe River Commission, \\ Ministry of Water Resources, Bengbu, China
}

Received: 25 March 2018

Accepted: 12 July 2018

\begin{abstract}
Biochar produced from sewage sludge could provide an important alternative to waste management practices while offering an opportunity to improve soil properties and reduce the risk of contamination from direct applications of sewage sludge soil amendments. We assessed the impacts of different rates of biochar application $\left(20,40,60 \mathrm{t} \mathrm{ha}^{-1}\right)$ to peanuts grown in a loamy sand soil in the North China Plain on composition of the soil microbial community, soil bulk density (BD), pH, total carbon (TC), total nitrogen (TN), C:N, available phosphorus (P), available potassium (K), dissolved organic carbon (DOC) and crop yield. We found that sewage sludge biochar application increased TC, TN, available $\mathrm{K}$, and $\mathrm{C}: \mathrm{N}$, and decreased soil $\mathrm{BD}$ and $\mathrm{pH}$ and had variable effects on DOC. Amendment with biochar increased microbial biomass and the proportion of Gram-positive bacteria, Gram-negative bacteria, fungi and Actinomycetes, while it decreased the ratios of groups of bacteria. The highest crop yield was achieved under $40 \mathrm{tha}^{-1}$ of biochar. Our study suggests that the lower rates of sewage sludge biochar application could improve soil physicochemical properties and increase levels of soil microbes and crop yield; however, the highest rate may induce negative effects on microbe community composition.
\end{abstract}

Keywords: application rate, field experiment, PLFA, soil properties, peanut productivity

\section{Introduction}

Increase of carbon fluxes among soil, plants and the atmosphere is a key driver of global warming [1, 2],

*e-mail: 236980110@qq.com and there has been recent interest in the application of biochar to soil as a potential climate change mitigation strategy, since it may act as a long-term carbon sink [3]. The effects of biochar on soil characteristics such as $\mathrm{pH}$, porosity, bulk density and cation exchange capacity suggest that its application could form part of a long-term climate change adaptation strategy [3]. 
Liang et al. [4] found that amending soil with biochar enhanced the specific surface area of a loamy sand soil and consequently had a greater potential cation exchange capacity and retention of dissolved organic matter than untreated, adjacent soil, while Zhao et al. [5] reported that biochar application increased the activity and biomass of soil microorganisms as a result of an associated increase in nutrients. Biochar application may also provide additional benefits to agriculture, since it improves crop yield and plant nutrient availability [6]. Sewage sludge, which is a globally ubiquitous carbon-rich material with reactive surfaces, may be pyrolized to biochar that is high in mineral ash content and could serve as a low-cost source of soluble essential plant nutrients [7].

The characteristic of loose texture of sand soil renders it difficult to retain moisture and nutrients, so agricultural productivity of these soils is generally low and insufficient to meet growing food demands. The North China Plain contains more than $25,800 \mathrm{~km}^{2}$ of loamy sand soils that is mostly distributed along the old course of the Yellow River in Henan Province. Biochar is generally applied to highly weathered, heavy soils, as an effective alternative for the enhancement of soil fertility and a range of soil physicochemical properties, but the benefits of biochar application to lighter, loamy sand soils have been little studied $[8,9]$.

Microbial phospholipid fatty acid (PLFA) profiling analysis is commonly used to assess soil microbial community abundance that is widely used as an indicator of soil quality changes due to the sensitivity to environmental change [10]. Microbial community responses to biochar application vary depending on a range of factors, including biochar type [11], where dominant effects of biochar on community composition are changes in substrate availability and $\mathrm{pH}$ [12]. For example, Quilliam et al. [13] reported that biochar application could produce and absorb polycyclic aromatic hydrocarbons that are known to interfere with microbes, while Steinbeiss et al. [14], who used PLFA analysis, observed that soil amended with yeast biochar increased fungi and Gram-negative bacterial biomass. Khan et al. [15] reported that sewage sludge biochar increased shoot biomass, grain yield, and the bioaccumulation of phosphorus in rice. To our knowledge, few studies have examined the effects of biochar application on soil characteristics and crop yield in loamy sand soils, particularly in the warm temperate region of the North China Plain, and in those studies that have been reported, the assessed effects of biochar were mostly derived from plants or manure rather than sewage sludge. The objectives of this study were to evaluate the effects of sewage sludge biochar application on soil physicochemical properties, microbial community composition and crop yield in a loamy sand soil, and to illustrate the main factors that drive changes in microbial community composition following biochar addition.

\section{Materials and Methods}

\section{Experimental Site and Biochar}

Soil samples were collected from the HuaiWei Wind Erosion Observation Point in Yifeng $\left(114^{\circ} 57^{\prime} 12.13^{\prime \prime} \mathrm{E}\right.$, $34^{\circ} 48^{\prime} 00.59^{\prime \prime} \mathrm{N}$; $66 \mathrm{~m}$ elevation), on the Central Great Plain of the Yellow Huai River in northern China that is characterized by a warm temperate monsoon climate with a mean annual temperature of $14.2^{\circ} \mathrm{C}$, and mean annual precipitation of c. $678.2 \mathrm{~mm}$, most of which is confined to a 4-month period from June to September. According to the United States Department of Agriculture texture classification system, the soil texture is loamy sand (FAO) with $821 \mathrm{~g} \mathrm{~kg}^{-1}$ sand, $124 \mathrm{~g} \mathrm{~kg}^{-1}$ silt, and $55 \mathrm{~g} \mathrm{~kg}^{-1}$ clay. The observation point was set up in September 2015, and before this the soil was traditionally cultivated under crops for at least 30 years.

The experimental site was prepared by clearing weeds, moldboard ploughing and harrowing to a depth of c. $30 \mathrm{~cm}$. The experiment comprised three replicates of four treatments (Table 1) arranged in a randomized block design in plots $(5 \times 8 \mathrm{~m}$, with $0.25 \mathrm{~m}$ between rows) separated by a $1-\mathrm{m}$ buffer zone. Inorganic fertilizers and biochar amendments were incorporated to a $30-\mathrm{cm}$ depth before peanut (cv. No.16 Huayu) was drilled in 2016 and 2017; there were no amendments in 2017. Mature peanuts were harvested on 20 September 2016 and 26 September 2017.

Biochar was produced from municipal sewage sludge from a treatment plant and prepared using the cracking process in a reactor [16] at the Mississippi International Water Company. The dry sewage sludge was combusted under "no-oxygen" conditions using slow-pyrolysis in a muffle furnace, where the pyrolysis temperature was raised at a rate of $26^{\circ} \mathrm{C} \mathrm{min}-1$ and then held at 700 to $850^{\circ} \mathrm{C}$ for $4 \mathrm{~h}$. It is expected that $10 \%$ of the mass of sewage sludge is converted to biochar using this process. The biochar was passed through a 2-mm sieve prior to hand-broadcasting it onto the soil surface, and then using a tilling tractor to ensure even mixing within the top $30 \mathrm{~cm}$ of soil. The physicochemical properties of biochar are presented in Table 2; metal content did not exceed the threshold of China Environmental Protection Agency standards [17-18].

Table 1. Sewage sludge treatments and associated nitrogen $(\mathrm{N})$, phosphorous $(\mathrm{P})$, and potassium $(\mathrm{K})$ content $\left(\mathrm{kg} \mathrm{ha}^{-1}\right)$

\begin{tabular}{|c|c|c|c|c|}
\hline $\begin{array}{c}\text { Treatment } \\
\text { Code }\end{array}$ & $\begin{array}{c}\text { Biochar Application } \\
\text { Rate }\end{array}$ & $\mathrm{N}$ & $\mathrm{P}$ & $\mathrm{K}$ \\
\hline $\mathrm{CK}$ & $0 \mathrm{tha}^{-1}$ & 0 & 0 & 0 \\
\hline $\mathrm{B} 20$ & $20 \mathrm{tha}^{-1}$ & 332 & 342 & 54 \\
\hline $\mathrm{B} 40$ & $40 \mathrm{tha}^{-1}$ & 664 & 684 & 108 \\
\hline $\mathrm{B} 60$ & $60 \mathrm{tha}^{-1}$ & 996 & 1026 & 162 \\
\hline
\end{tabular}


Table 2. Physicochemical properties of pre-treated soils and biochar.

\begin{tabular}{|c|c|c|}
\hline Elements & Soil & Biochar \\
\hline $\mathrm{pH}$ & 8.8 & 6.4 \\
\hline $\mathrm{MC}(\mathrm{unit})$ & 4.5 & 9.7 \\
\hline $\mathrm{BD}\left(\mathrm{g} \mathrm{cm}^{-3}\right)$ & 1.39 & $/$ \\
\hline Total carbon $\left(\mathrm{g} \mathrm{kg}^{-1}\right)$ & 9.3 & 197.7 \\
\hline Total N $\left(\mathrm{g} \mathrm{kg}^{-1}\right)$ & 0.68 & 16.6 \\
\hline Total P $\left(\mathrm{g} \mathrm{kg}^{-1}\right)$ & 0.98 & 17.1 \\
\hline Total $\mathrm{K}\left(\mathrm{g} \mathrm{kg}^{-1}\right)$ & 12.79 & 2.7 \\
\hline Volatile matter $(\mathrm{wt} \%)$ & $/$ & 11.8 \\
\hline Fixed carbon $\left.(\mathrm{wt} \%)^{\circ}\right)$ & $/$ & 29.4 \\
\hline Ash $(\mathrm{wt} \%)$ & $/$ & 58.8 \\
\hline BET sufrace area $\left(\mathrm{m}^{2} \mathrm{~g}^{-1}\right)$ & $/$ & 14.2 \\
\hline
\end{tabular}

\section{Soil Physicochemical Properties and Crop Yield Analysis}

Soil samples were collected on 10 May 2016 (prior to drilling) and at the end of growing season in 2017 in order to assess the treatment effects on soil properties after applying biochar for two years. Composite soil samples were taken from a depth of $0-15 \mathrm{~cm}$ using a $4-\mathrm{cm}$ diameter soil core sampler sealed in a plastic bag, stored on ice and then shipped to the laboratory within $24 \mathrm{~h}$. A portion of the fresh soil samples was stored at $4^{\circ} \mathrm{C}$ for dissolved organic carbon (DOC), while the remaining sample was air-dried and passed through a 2-mm sieve. Large plant debris and roots were removed before sieving and there was no visually recognizable loss of biochar from soil during this process.

Soil bulk density (BD) was determined from soil samples that were oven dried at $105^{\circ} \mathrm{C}$ until a constant weight had been achieved. Soil $\mathrm{pH}$ was determined from a soil-to-water ratio of 1:5 using a PB-10 pH meter (Sartorius GmbH, Göttingen, Germany) [11], and content of soil total carbon (TC) and total nitrogen (TN) was determined using an elemental analyzer (Elementar, Vario EL, Germany). Soil-available phosphorus (P) was determined using sodium bicarbonate, and soil-available potassium (K) was determined using ammonium acetate [2]. Soil DOC was measured according to the method reported by $\mathrm{Lu}$ and Zhang [19], where fresh soil samples (10 g dry equivalent) and ultrapure water $(25 \%, \mathrm{w} / \mathrm{v})$ were shaken for $30 \mathrm{~min}$ on a reciprocal shaker $(250 \mathrm{r}$ min- -1$)$ at $25^{\circ} \mathrm{C}$ and then centrifuged at $4000 \mathrm{rpm}$ for $10 \mathrm{~min}$. The supernatant was filtered using a $0.45 \mu \mathrm{m}$ cellulose ester filter and measured using a TOC analyzer (TOC-VCPH+TNM-1, Shimazu Inc, Japan).

Crop yield of the plots was determined after harvest at the end of growing seasons in 2016 and 2017, where 10 plants were randomly removed from the center two rows of each plot, and roots were cleaned and oven-dired at $80^{\circ} \mathrm{C}$ to a constant dry weight. Yield samples were collected on the same day using an inverting digger, and pods were removed from the plants using a commercial peanut combine harvester.

\section{Phospholipid Fatty Acid (PLFA) Analysis}

Soil sampled as above was stored at $-70^{\circ} \mathrm{C}$ prior to extraction and quantification of PLFA based on the method described by Guo et al. [20]. For the microbial analysis, lipids were extracted from $3 \mathrm{~g}$ of soil in a solution of methanol $(8 \mathrm{ml})$, chloroform $(4 \mathrm{ml})$ and phosphate buffer $(3.2 \mathrm{ml}, 0.15 \mathrm{M})$. Neutral lipids, glycolipids and phospholipids were separated from polar lipids on a silica-bonded phase column (SepPak Silica SPE, Waters Corp, USA) sequentially eluted with chloroform, acetone and methanol, respectively. The purified phospholipids were saponified and methylated to extract the fatty acid methyl esters (FAME) at $37^{\circ} \mathrm{C}$ in a water bath, and acid levels were reduced using sodium hydroxide before drying under a stream of $\mathrm{N} 2$ at $25^{\circ} \mathrm{C}$. FAME were quantified and identified using gas chromatography coupled to mass spectrometry (Hewlett Packard, Agilent 5973 Plus HP6890 Series GC-System) with a cross-linked 5\% phenyl methyl rubber phase (film thickness of $0.35 \mathrm{~mm}$ ). The internal standard (C19:0) peak areas were expressed as nmol g-1 dry soil and used as a reference to calculate the concentration of PLFA.

Total microbial biomass (total PLFA) was estimated using total nmol $\mathrm{g}^{-1}$ dry soil as an index. PLFA was divided into taxonomic groups based on previously published PLFA biomarker data [21] that included Grampositive $(\mathrm{Gram}+)$ bacteria (sum of i14:0, i15:0, i16:0, i17:0, a15:0, a17:0), Gram-negative (Gram-) bacteria

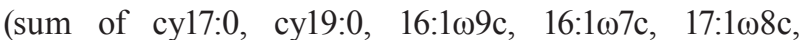
18:1 $\omega 5 \mathrm{c}$ ), total bacterial biomass (sum of Gram+ and Gram- bacteria biomarkers together with 15:0, 17:0,

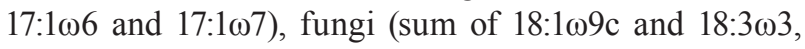
6,9 ), and Actinomycetes (sum of 10Me-16:0, 10Me-17:0, 10Me-18:0).

\section{Statistical Analysis}

Treatment effects of biochar were analyzed using one-way ANOVA in SPSS 16.0 software package for Windows (SPSS Chicago, II, USA), with Duncan's multiple range test, based on least significant difference (LSD) values at $\mathrm{P}<0.05$ to test for variation among treatments. Principal component analyses (PCA) and redundancy discriminant analyses (RDA) were used to explore the relationships between the soil microbial community and soil physicochemical properties using Canoco 5. Person correlation tests were applied to explore the association between soil microbial community and crop yield. 


\section{Results and Discussion}

\section{Soil Physicochemical Properties}

Physicochemical properties of the sewage sludge biochar are presented in Table 2. After two years, biochar had reduced soil BD (Fig. 1a), although there was no difference between the two high rates (B40 and B60). Biochar is an effective soil conditioner and its effect on BD may be explained by a simple dilution effect on the soil of the low bulk density biochar [22]. In our study, all biochar treatments decreased soil BD, which was consistent with many other field studies [23-24]. However, we found that there was no difference in treatment effect between the two high rates of biochar (40 and $60 \mathrm{t} \mathrm{ha}^{-1}$ ). Similar results have been reported by Zhang et al. [25], who showed that wheat straw biochar applied to soil at 20 and $40 \mathrm{Mg} \mathrm{ha}^{-1}$ had no effect on soil BD. This indicated that excessive rates of biochar application would not help continue to decrease soil BD.

We found that sewage sludge biochar reduced soil $\mathrm{pH}$ by $0.2-0.55$ units, where $\mathrm{pH}$ decreased with increasing rate of biochar addition (Fig. 1b). While this result is consistent with some studies [26-27], others have shown that soil $\mathrm{pH}$ was increased [28] or was not
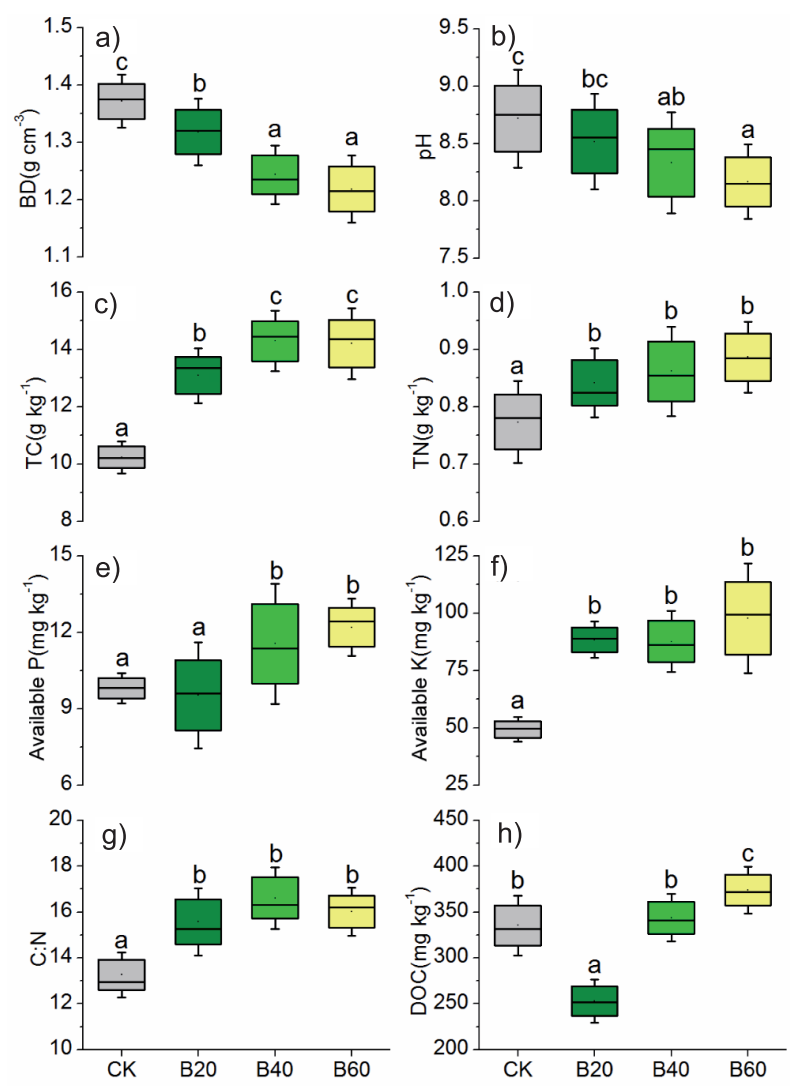

Fig. 1. Soil physicochemical properties under different treatments; boxes represent half of the data, the thick line within each box represents median value, and whiskers represent interquartile ranges influenced [11] by biochar application. This difference in response of soil $\mathrm{pH}$ to biochar addition may be due to differences in biochar production material and soil types [29]. Biochar amendment has been reported to have a neutralizing effect on soil $\mathrm{pH}$ in acidic soil [30], which may be attributed to the content of carbonates of alkali and alkaline earth metals, variable amounts of silica, phosphates and small amounts of organic and inorganic $\mathrm{N}$. As found in this study, decreased soil $\mathrm{pH}$ is favorable to microbial activities that are known to contribute to $\mathrm{N}$ and $\mathrm{P}$ availability in soils [31] and this was found in our study.

Although soil $\mathrm{TC}$ and $\mathrm{TN}$ concentrations were increased by the addition of sewage sludge biochar, there was no difference in TN content among the treatments (Fig. 1c-d). The higher levels of TC and TN content under biochar application are consistent with previous reports [32-33] and may be a result of the response of non-decomposed $\mathrm{C}$ and $\mathrm{N}$ in the organic sewage sludge biochar after two years.

Available $\mathrm{P}$ concentrations in the $\mathrm{B} 40$ and $\mathrm{B} 60$ treatments were increased by 17.74 and $24.37 \%$, respectively (Fig. 1e), and while available $\mathrm{K}$ and soil $\mathrm{C}: \mathrm{N}$ ratio were increased by the addition of sewage sludge biochar, there were no differences among the treatments (Fig. 1f-g). The increased in soil C:N ratio in the biochar treatments may be due to the inherent high $\mathrm{C}: \mathrm{N}$ ration of biochar, as reported by Laghari et al. [34]. Nelissen et al. [35] similarly reported a positive effect of biochar addition on soil $\mathrm{K}$ availability in a sandy loam soil during a two-year field experiment, possibly due to its enhancement of cation exchange [2]. The increase in the release of $\mathrm{K}$ cations from the soil surface colloid to the soil solution subsequently increased available $\mathrm{K}$ concentration in the biochar treatments. The lack of difference in available $\mathrm{K}$ among the biochar treatments indicates that biochar application rate should be controlled. Since the B20 treatment had no effect on soil available P, as also reported by Lentz and Ippolito [36], it is possible that only higher rates of biochar increase available $\mathrm{P}$ in acidic soils.

The concentration of soil DOC was decreased by the lowest rate of biochar addition and increased by the highest rate, but there was no difference at the midrate of application (Fig. 1h). The addition of biochar has been shown to stimulate microbial use soil DOC [37], but the physical adsorption of DOC by biochar may explain the decrease in DOC concentration at the low rate of biochar addition (B20) [37]. High rates of biochar application contain toxic elements that may suppress microbial community composition and associated use of DOC; this may explain our results that showed higher DOC concentrations under the highest rate of biochar application.

\section{Soil Microbial Community}

PLFA concentrations were increased by biochar two years after application (Fig. 2). Although we 

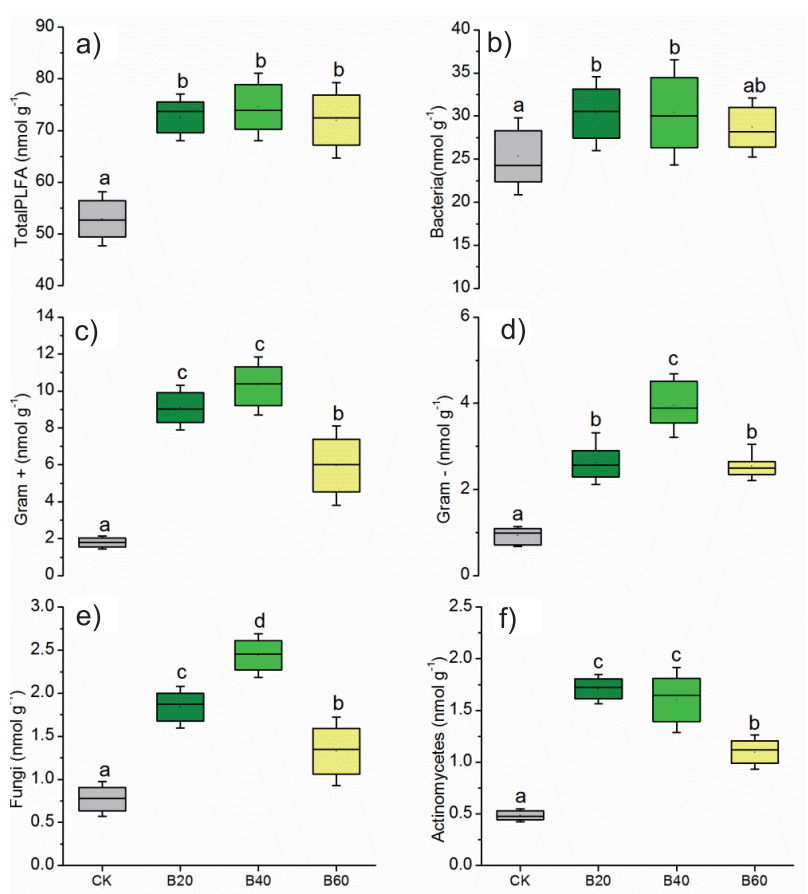

Fig. 2. Relative abundance of different microbial groups under different treatments; boxes represent half of the data, the thick line within each box represent median value, and whiskers represent interquartile ranges.

found there were no differences in total PLFA and bacteria among the biochar treatments (Fig. 2a-b), there were lower densities of Gram+, Gram-, fungi and Actinomycetes under the highest rate of biochar (Fig. 2c-f). Biochar increased the proportion of Gram+, Gram-, fungi and Actinomycetes, but decreased the proportion of bacteria (Table 3). Among the biochar treatments, B40 had the highest proportion of Gram+, Gram-, fungi and Actinomycetes; the increase of biochar rate from 40 to $60 \mathrm{t} \mathrm{ha}^{-1}$ led to a decrease in the proportions of Gram+, Gram-, fungi and Actinomycetes. These results may be due to the effects of toxic elements of biochar, which are known to suppress microbial community composition [38-40], and indicate that the application of high amounts of sewage sludge biochar (60 $\left.\mathrm{t} \mathrm{ha}^{-1}\right)$ could inhibit soil microbial biomass for at least two years in a sandy loam soil.
PCA is a statistic technique to determine treatment differentiation of combinations of variables or parameters [41]. We found that principal components (PCs) 1 and 2 accounted for $84.56 \%$ and $6.59 \%$ of the total variation in soil microbiological and physicochemical properties, respectively (Fig. 3a). PC1 tended to separate the biochar treatments from the control, where the biochar treatments were associated with high levels of microbial biomass (Gram+ and Actinomycetes), and high levels of $\mathrm{BD}$ and $\mathrm{pH}$ were associated with the untreated control soils. In general, PCA showed distinct microbial and physicochemical properties of the untreated soils, and each biochar treatment after two years, where those of the biochar treatments were more similar to each other.

Soil microbial community composition has been widely used as an indicator of soil characteristics because of its sensitivity to environmental change [10]. Potential mechanisms of the effects of biochar on soil microbial community composition include the provision of carbon material, production and/or adsorbance of substances that stimulate or inhibit microbes, and provision a suitable habitat for microbial growth and protection from predators [37]. In our study, additional organic matter in biochar stimulated different groups of soil microorganism, and as a result, soil TC was positively correlated with all biomarker PLFAs. All biomarker PLFAs were influenced by biochar, regardless of application rate, possibly due to effects on $\mathrm{pH}$ that stimulated soil microbial biomass and changed the microbial community composition $[42,43]$.

RDA combines regression and PCA to allow direct analysis of the structuring of a set of response variables by explanatory variables [44]. We found that axes 1 and 2 accounted for $82.89 \%$ and of the variation in microbial community composition of PLFA profiles related to soil physicochemical properties, respectively, where Monte Carlo permutation tests of the first canonical axis and the sum of all canonical axes were $\mathrm{F}=72.7, \mathrm{P}=0.002$ and $\mathrm{F}=12.0, \mathrm{P}=0.002$, respectively (Fig. 3b); microbial community composition was positively correlated with soil $\mathrm{TC}, \mathrm{C}: \mathrm{N}$ and available $\mathrm{K}$, and negatively correlated $\mathrm{pH}$ and $\mathrm{BD}$. It is widely accepted that $\mathrm{BD}$ and $\mathrm{pH}$ affect soil microbial community composition $[42,45]$, and in our study RDA showed that biochar altered soil characteristics by decreasing soil $\mathrm{BD}$ and $\mathrm{pH}$ and affecting the soil nutrient pool. Biochar

Table 3. Effect of sewage sludge biochar application rate on proportion (\%) of microbial groups characterized by phospholipid fatty acids.

\begin{tabular}{|c|c|c|c|c|c|}
\hline Treatment & Bac/PLFA & Gram+/PLFA & Gram-/PLFA & Fungi/PLFA & Act/PLFA \\
\hline CK & $47.86 \pm 4.45 \mathrm{a}$ & $3.39 \pm 0.32 \mathrm{c}$ & $1.76 \pm 0.35 \mathrm{c}$ & $0.92 \pm 0.12 \mathrm{c}$ & $1.46 \pm 0.26 \mathrm{~d}$ \\
\hline B20 & $41.90 \pm 5.50 \mathrm{~b}$ & $12.54 \pm 0.76 \mathrm{a}$ & $3.64 \pm 0.76 \mathrm{~b}$ & $2.35 \pm 0.11 \mathrm{a}$ & $2.53 \pm 0.15 \mathrm{~b}$ \\
\hline B40 & $40.63 \pm 3.20 \mathrm{~b}$ & $13.79 \pm 1.43 \mathrm{a}$ & $5.34 \pm 1.02 \mathrm{a}$ & $2.15 \pm 0.29 \mathrm{a}$ & $3.28 \pm 0.29 \mathrm{a}$ \\
\hline B60 & $40.24 \pm 6.05 \mathrm{~b}$ & $8.40 \pm 2.39 \mathrm{~b}$ & $3.54 \pm 0.45 \mathrm{~b}$ & $1.53 \pm 0.21 \mathrm{~b}$ & $1.86 \pm 0.45 \mathrm{c}$ \\
\hline
\end{tabular}

Different letters within a column indicate treatment differences at $P<0.05$. 

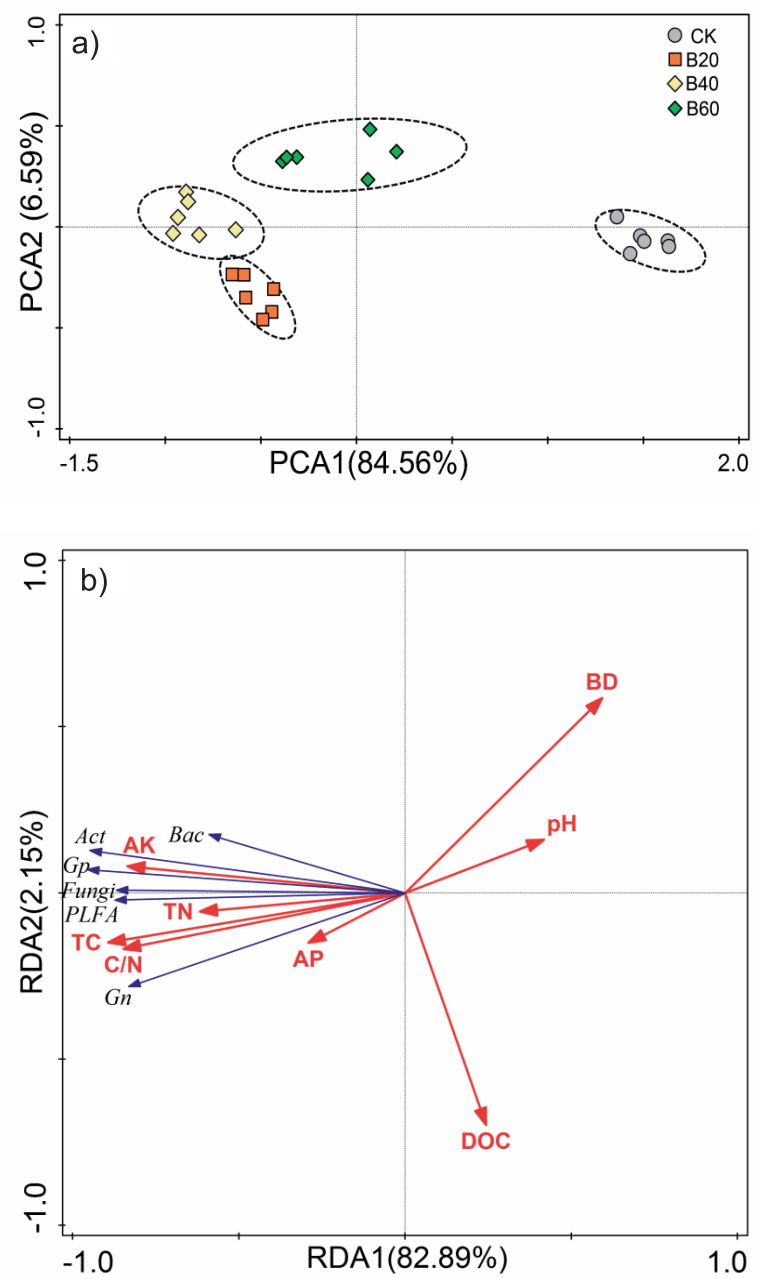

Fig. 3. Principal component analysis of the soil microbiological and physicochemical prosperities of the treatments a) and redundancy analysis of the correlations among soil parameters and microbial community composition b); blue arrows are microbial groups and red arrows indicate the parameters that were related to microbial community composition $(P<0.05)$; the angle and length of the arrows indicate the direction and strength of the relationship; PLFA - total PLFA, Bac - bacteria, Gp - Gram positive bacteria, Gn - Gram negative bacteria, Act actinobacteria, $\mathrm{BD}$ - bulk density, TC - total carbon, TN - total nitrogen, $\mathrm{AP}$ - available phosphorus, $\mathrm{AK}$ - available potassium, DOC - dissolved organic carbon.

application that reduced soil $\mathrm{BD}$ and improved root growth and increased root biomass probably explain the higher microbial biomass in the biochar treatments [24]. We also found changes to microbial community composition among the treatments, and these changes that were correlated with soil C content were consistent with previous reports $[38,42]$. It is possible to reason that the mineralization of organic matter increased the biomass of soil microorganisms.

\section{Crop Yield}

We found that the addition of biochar at 20, 40 and $60 \mathrm{t} \mathrm{ha}^{-1}$ increased crop yield by 34.72, 60.43 and $52.29 \%$, respectively, where crop yield of the B20 treatment was lower than the B40 and B60 treatments, and there was no difference in crop yield between these higher rates (Table 4).

Biochar decreased soil BD and may have acted as a soil conditioner that retained more available water and nutrients, and improved root growth which subsequently enhanced crop yield [24]. Biochar application may have increased soil temperatures during seed germination, mitigate drought, improved soil structure and aggregate formation and reduced weed competition [18] - which are all beneficial to crop yield. The higher rates of available $\mathrm{P}$ and $\mathrm{K}$ indicate that the biochar amendment may provide a slow-release of $\mathrm{P}$ and $\mathrm{K}$, in additional to that provided by the application of conventional fertilizer, through mineralization reactions [46]. Although studies have shown a clear enhanced effect of biochar on crop yield in sandy soil with low fertility [46], we found that the increase in application rate of biochar from 40 to $60 \mathrm{t} \mathrm{ha}^{-1}$ did not change crop yield, and we suggest the rate should be optimized to $40 \mathrm{t} \mathrm{ha}^{-1}$ of sewage sludge biochar. The highest positive correlation with crop yield was Gram- bacteria $\left(\mathrm{r}=0.71^{* *}\right)$ (Table 5), probably because various Gram- bacteria families contain a plant growth-promoting member [47]. In our study, the increase in crop yield may have been due to improved nutrient availability mediated by biochar amendment, as a result of effects on soil physicochemical properties.

\section{Conclusions}

Our two-year consecutive field experiment in the North China Plain revealed that the application of sewage sludge biochar positively affected soil characteristics and crop yield. Strong correlations among microbial community composition, soil physicochemical properties and crop yield indicated that microbial community composition and crop yield were strongly affected by physicochemical properties. The stimulation of the microbial community composition by biochar was primarily due to changes in soil physicochemical properties - especially decreases in $\mathrm{BD}$ and $\mathrm{pH}$. The strong positive correlation between crop yield and microbial community composition indicated that the

Table 4. Effect of sewage sludge biochar application rate on crop yield.

\begin{tabular}{|c|c|c|c|c|}
\hline Treatment & CK & B20 & B40 & B60 \\
\hline Crop yield $\left(\mathrm{kg} \mathrm{ha}^{-1}\right)$ & $2863 \pm 214 \mathrm{a}$ & $3857 \pm 305 \mathrm{~b}$ & $4593 \pm 152 \mathrm{c}$ & $4360 \pm 217 \mathrm{c}$ \\
\hline
\end{tabular}

Different letters indicate treatment differences at $P<0.05$. 
Table 5. Pearson's correlation between microbial community composition and crop yield.

\begin{tabular}{|c|c|c|c|c|c|c|}
\hline Microbial composition & Total PLFA & Bacteria & Gram+ & Gram- & Fungi & Actinomycetes \\
\hline Yield & $0.50^{* *}$ & 0.23 & $0.65^{* *}$ & $0.71^{* *}$ & $0.64^{* *}$ & $0.60^{* *}$ \\
\hline
\end{tabular}

change of soil microbial community composition may have led to the increase in crop yield. Our results demonstrate that the biochar application is beneficial to the improvement of soil properties and has potential as an effective measure for improving crop yield. It is likely that high rates of sewage sludge biochar amendment $\left(60 \mathrm{t} \mathrm{ha}^{-1}\right)$ would not continue to elicit benefits in soil properties or crop yield, but application them at $40 \mathrm{t} \mathrm{ha}^{-1}$ would likely be an optimal rate of amendment to loamy sand soils for at least two years. In the future, long-term comprehensive evaluations are needed to improve knowledge about the effect of sewage sludge biochar on the composition of the soil microbial community in the midland area of China.

\section{Acknowledgements}

The authors are highly grateful to the people who provided valuable suggestions and constructive comments on the manuscript. This work was financially supported by the Monitoring Program of Wind Erosion in Huai River Basin from the Huai River Commission of Water Resources Ministry (grant No. HWSBC2016003).

\section{Conflict of Interest}

The authors declare no conflict of interest.

\section{References}

1. MUHAMMAD N., DAI Z., XIAO K. Changes in microbial community structure due to biochars generated from different feedstocks and their relationships with soil chemical properties. Geoderma. 226, 270, 2014.

2. EL-NAGGAR AH., USMAN AR., AL-OMRAN A., OK YS., AHMAD M., AL-WABEL MI. Carbon mineralization and nutrient availability in calcareous sandy soils amended with woody waste biochar. Chemosphere. 138, 67, 2015.

3. NELISSEN V., RUYSSCHAERT G., MANKA ABUSI D. Impact of a woody biochar on properties of a sandy loam soil and spring barley during a two-year field experiment. European Journal of Agronomy. 62, 65, 2015.

4. LIANG B., LEHMANN J., SOLOMON D. Black carbon increases cation exchange capacity in soil. Soil Science Society of America Journal. 70, 1719, 2006.

5. ZHAO R., COLES N., WU J. Carbon mineralization following additions of fresh and aged biochar to an infertile soil. Catena 125, 183, 2015.

6. LU W., DING W., ZHANG J. Biochar suppressed the decomposition of organic carbon in a cultivated sandy loam soil: A negative priming effect. Soil Biology \& Biochemistry. 76, 12, 2014.

7. GASCO G., PAZ-FERREIRO J., MENDEZ A. Thermal analysis of soil amended with sewage sludge and biochar from sewage sludge pyrolysis. Journal of Thermal Analysis \& Calorimetry. 108, 769, 2012.

8. DU Z.L., ZHAO J.K., WANG Y.D., ZHANG Q.Z. Biochar addition drives soil aggregation and carbon sequestration in aggregate fractions from an intensive agricultural system. Journal of Soils \& Sediments. 17 (3), 1, 2017.

9. VERHEIJEN F.G.A., GRABER E.R., AMELOOT N., BASTOS A.C., SOHI S., KNICKER H. Biochars in soils: new insights and emerging research needs. European Journal of Soil Science. 65 (1), 22, 2014.

10. CHENG H., HILL P.W., BASTAMI M.S., JONES D.L. Biochar stimulates the decomposition of simple organic matter and suppresses the decomposition of complex organic matter in a sandy loam soil. Global Change Biology Bioenergy. 9 (6), 2017.

11. SANDHU S.S., DAN U., KUMAR S. Analyzing the impacts of three types of biochar on soil carbon fractions and physiochemical properties in a corn-soybean rotation. Chemosphere. 184, 473, 2017.

12. FIERER N., STRICKLAND M.S., LIPTZIN D., BRADFORD M.A., CLEVELAND C.C. Global patterns in belowground communities. Ecology Letters. 12 (11), 1238, 2009.

13. QUILLIAM R.S., MARSDEN K.A., GERTLER C., ROUSK J., DELUCA T.H., JONES D.L. Nutrient dynamics, microbial growth and weed emergence in biochar amended soil are influenced by time since application and reapplication rate. Agriculture Ecosystems \& Environment. 158 (1), 192, 2012.

14. STEINBEISS S., GLEIXNER G., ANTONIETTI M. Effect of biochar amendment on soil carbon balance and soil microbial activity. Soil Biology \& Biochemistry. 41 (6), 1301, 2009.

15. KHAN S., CHAO C., WAQAS M., ARP H.P., ZHU Y.G. Sewage sludge biochar influence upon rice (Oryza sativa L) yield, metal bioaccumulation and greenhouse gas emissions from acidic paddy soil. Environmental Science \& Technology. 47 (15), 8624, 2013.

16. ZHANG DA WEI. Faming Zhuangli Shenqing Gongkai Shuomingshu. CN 101921595B, 2014 [In Chinese].

17. YAO J.L., WANG H.Y., YU Y.J., WANG Q., WANG X.R. Pollution status and characteristics of heavy metals in sewage sludge from municipal wastewater treatment plants. Research of Environmental Sciences. 23 (6), 696, 2010.

18. PRENDERGASTMILLER M. Biochar field testing in the UK: outcomes and implications for use. Carbon Management. 4 (2), 159, 2013.

19. LU W., ZHANG H. Response of biochar induced carbon mineralization priming effects to additional nitrogen in a sandy loam soil. Applied Soil Ecology. 96, 165, 2015.

20. GUO X., CHEN HYH., MENG M., BISWAS S.R., YE L., ZHANG J. Effects of land use change on the composition of soil microbial communities in a managed subtropical forest. Forest Ecology \& Management. 373, 93, 2016. 
21. AI C., LIANG G., SUN J., WANG X., ZHOU W. Responses of extracellular enzyme activities and microbial community in both the rhizosphere and bulk soil to long-term fertilization practices in a fluvo-aquic soil. Geoderma. 173 (2), 330, 2012.

22. LAIRD D A., FLEMING P., DAVIS D.D., HORTON R., WANG B.Q., KARLEN D.L. Impact of biochar amendments on the quality of a typical Midwestern agricultural soil. Geoderma. 158 (3), 443, 2010.

23. LONE A.H., NAJAR G.R., GANIE M.A., SOFI J.A., ALI T. Biochar for Sustainable Soil Health: A Review of Prospects and Concerns. PEDOSPHERE. 25 (5), 639, 2015.

24. OBIA A., MULDER J., MARTINSEN V., CORNELISSEN G., BORRESEN T. In situ effects of biochar on aggregation, water retention and porosity in light-textured tropical soils. Soil \& Tillage Research. 155, 35, 2016.

25. ZHANG A., BIAN R., PAN G. Effects of biochar amendment on soil quality, crop yield and greenhouse gas emission in a Chinese rice paddy: A field study of 2 consecutive rice growing cycles. Field Crops Research. 127, 153, 2012.

26. YUAN J H. Comparison of the ameliorating effects on an acidic ultisol between four crop straws and their biochars. Journal of Soils \& Sediments. 11 (5), 741, 2011.

27. LAGHARI M., MIRJAT M.S., HU Z., FAZAL S., XIAO B., HU M. Effects of biochar application rate on sandy desert soil properties and sorghum growth. Catena. 135, 313, 2015.

28. MENDEZ A., GOMEA A., PAZ-FERREIRO J., GASCO G. Effects of sewage sludge biochar on plant metal availability after application to a Mediterranean soil. Chemosphere. 89 (11), 1354, 2012.

29. CELY P., TARQUIS A.M., PAZFERREIRO., MENDEZ A., GASCO G. Factors driving the carbon mineralization priming effect in a sandy loam soil amended with different types of biochar. Solid Earth. 6 (1), 1748, 2014.

30. PURAKAYASTHA T.J., DAS K.C., GASKIN J., HARRIS K., SMITH J.L., KUMARI S. Effect of pyrolysis temperatures on stability and priming effects of $\mathrm{C} 3$ and C4 biochars applied to two different soils. Soil \& Tillage Research. 155 (4), 107, 2016.

31. USDA. Soil quality test kit guide. USDSA, Washington. USA, 1999.

32. LIANG X.Q., JI YJ., HE M.M., SU M.M., LIU C., TIAN G.M. Simple N Balance Assessment for Optimizing the Biochar Amendment Level in Paddy Soils. Communications in Soil Science \& Plant Analysis. 45 (9), 1247, 2014.

33. OUYANG L., YU L., ZHANG R. Effects of amendment of different biochars on soil carbon mineralisation and sequestration. Soil Research. 52 (1), 46, 2014.

34. LAGHARI M., MIRJAT M.S., HU Z. Effects of biochar application rate on sandy desert soil properties and sorghum growth. Catena. 135, 313, 2015.
35. NELISSEN V., RUTTING T., HUYGENS D., RUYSSCHAERT G., BOECKX P. Temporal evolution of biochar's impact on soil nitrogen processes \&ndash; a 15N tracing study. Global Change Biology Bioenergy. 7, 635, 2015.

36. LENTZ R.D., IPPOLITO J.A. Biochar and manure affect calcareous soil and corn silage nutrient concentrations and uptake. Journal of Environmental Quality. 41 (4), 1033, 2012.

37. DEMISIE W., LIU Z., ZHANG M. Effect of biochar on carbon fractions and enzyme activity of red soil. Catena. 121 (5), 214, 2014.

38. WANG X., SONG D., LIANG G., ZHANG Q., AI C., Zhou W. Maize biochar addition rate influences soil enzyme activity and microbial community composition in a fluvoaquic soil. Applied Soil Ecology. 96, 265, 2015.

39. DEMPSTER D.N., GLEESON D.B., SOLAIMAN Z.M., JONES D.L., MURPHY D.V. Decreased soil microbial biomass and nitrogen mineralisation with Eucalyptus biochar addition to a coarse textured soil. Plant \& Soil. 354 (1), 311, 2012.

40. CAO X.D., HARRIS W. Properties of dairy-manurederived biochar pertinent to its potential use in remediation. Bioresource Technology. 101 (14), 5222, 2010.

41. FONTURBEL M.T., BARREIRO A., VEGA J.A. Effects of an experimental fire and post-fire stabilization treatments on soil microbial communities. Geoderma. 191 (12), 51, 2012.

42. AI C., LIANG G., SUN J. The alleviation of acid soil stress in rice by inorganic or organic ameliorants is associated with changes in soil enzyme activity and microbial community composition. Biology \& Fertility of Soils. 51 (4), 465, 2015.

43. ACUNA J.J., JORQUERA M.A., MARTINEZ O.A., MENEZESBLACKBUM D., FERNANDEZ M.T., MARSCHNER P. Indole acetic acid and phytase activity produced by rhizosphere bacilli as affected by $\mathrm{pH}$ and metals. Journal of soil science \& Plant nutrition. 11 (3), 1, 2011.

44. DANIEL BORCARD., FRANCOIS GILLET., PIERRE LEGENDRE. Numerical ecology with R. Matisse. 75 (5), 332-, 2011.

45. LIU X., ZHANG B., ZHAO W. Comparative effects of sulfuric and nitric acid rain on litter decomposition and soil microbial community in subtropical plantation of Yangtze River Delta region. Science of the Total Environment. 601, 669, 2017.

46. AGEGNEHU G., BASS A.M., NELSON P.N., MUIRHEAD B., WRIGHT G., BIRD M.I. Biochar and biochar-compost as soil amendments: Effects on peanut yield, soil properties and greenhouse gas emissions in tropical North Queensland, Australia. Agriculture Ecosystems \& Environment. 213, 72, 2015.

47. MENDES R., RAAIJMAKERS J.M. Deciphering the Rhizosphere Microbiome for Disease-Suppressive Bacteria. Science. 332 (6033), 1097, 2011. 